\title{
26. STYLOLITES IN CHALK FROM LEG 130, ONTONG JAVA PLATEAU ${ }^{1}$
}

\author{
Ida L. Lind ${ }^{2}$
}

\begin{abstract}
Incipient stylolites and diffuse microstylolitic flaser structures occur in the chalk of Ocean Drilling Program Leg 130 cores below a depth of $470 \mathrm{mbsf}$. Well-developed stylolites are common in chalk and limestone below $830 \mathrm{mbsf}$. The stylolites and flaser structures appear to be localized along trace fossils, clasts of contrasting mineralogy, and color bands. A depth-dependent transition from color bands to flaser structures and possibly further to stylolites is postulated. The formation of either flaser structures or stylolites seems to depend upon whether the mineralogical anomalies localizing the structures are dispersed or concentrated.
\end{abstract}

\section{INTRODUCTION}

Stylolites have only rarely been described in Deep Sea Drilling Project (DSDP) and Ocean Drilling Program (ODP) cores. They were observed in the Aptian-Barremian limestone of Mediterranean Leg 13 (Ryan, Hsü, et al., 1973) and in Maastrichtian limestones of Leg 30 at the Ontong Java Plateau (Andrews, Packham, et al., 1975). It is probable that stylolites, especially the very fine ones, have been overlooked in other places. To find the spatial distribution of these structures in a deep-sea carbonate sedimentary column, special attention was given to note their presence during the routine description of cores from Leg 130.

Bathurst (1987) makes a distinction between stylolites and (microstylolitic) dissolution seams. He defines a stylolite as a serrated interface between two rock masses, in cross section of sutured appearance. The amplitude of the suture is greater than the diameters of the transected grains, and it cuts indiscriminately through the rock fabric. In contrast, dissolution seams are smooth, undulating, and lacking in sutures. These commonly anastomosing seams fit around grains instead of cutting through them. Grains of the host material commonly show evidence for dissolution at contact with the seam.

It may be impossible to differentiate between stylolites and solution seams in practice. In this paper, the terms "stylolites" and "microstylolites" are preferred. "Microstylolites" are so fine, that the unaided eye cannot tell whether they crosscut or fit around grains. For an anastomosing pattern of microstylolites ("a dissolution seam"), the noninterpretative term "flaser structure" is used. The interfaces of stylolites and microstylolites are covered by a thin layer ("drape") of a contrasting mineralogy to the host sediment. Drapes are typically clay rich. The stylolitic interfaces commonly have an overall horizontal orientation. In tectonically stressed areas they have orientations perpendicular to the direction of maximal stress. The overall stress-dependent orientation of the stylolites and the observed dissolution effects of the host material along the interfaces are the basis for assigning the enigmatic process of pressure dissolution to their formation.

In the present study, stylolites and flaser structures of the Ontong Java Plateau are described by (1) recording the number of stylolites and flaser structures as well as the suture amplitude and drape thickness for stylolites and microstylolites for each of the Hole 807C cores; and (2) investigating a possible isotopic anomaly stemming from the dissolution of carbonates along the stylolites and reprecipitation of carbonates near the stylolites.

\footnotetext{
'Berger, W.H., Kroenke, L.W., Mayer, L.A., et al., 1993. Proc. ODP, Sci. Results, 130: College Station, TX (Ocean Drilling Program).

${ }^{2}$ Instituttet for Geologi og Geoteknik, Danmarks Tekniske Højskole, Bygning 204, DK-2800 Lyngby, Denmark.
}

\section{GENERAL DESCRIPTION}

In the more than 1-km-thick, carbonate-dominated, sedimentary column of the Ontong Java Plateau, all stages - from microstylolites to well-developed stylolites - are seen. Core recoveries from Leg 130 are generally excellent; however, in the chert-rich, stylolite-bearing Oligocene and Eocene section between 780 and $1135 \mathrm{~m}$ below seafloor (mbsf) of Site 807, recoveries are generally poor (Fig. 1B). Save for the chert-rich interval, calcium carbonate contents in the stylolite- and flaser-structure-bearing sediments are around $90 \%$ or higher, the noncarbonate fraction is dominated by silicious fossils (Kroenke, Berger, Janecek, et al., 1991). Planar structures occur throughout the entire drilled carbonate section. The trace fossil Zoophycos is commonly observed, and green and purple color bands are common in the ooze and chalk section (Lind, Janecek, et al., this volume). With depth, color bands become wispy or slightly undulating and are described as flaser structures. This was noted in Hole 803D below $470 \mathrm{mbsf}$ in the Oligocene chalk. Flaser structures occur in the Miocene chalk of Hole 807A below 490 mbsf and of Hole 806B below 630 mbsf. Below 735 mbsf the colors are no longer green or purple, but gray flaser structures become common (Kroenke, Berger, Janecek, et al., 1991). Incipient stylolites are noted along Zoophycos burrows at $673 \mathrm{mbsf}$ in Hole $807 \mathrm{~A}$.

Well-developed stylolites are found in Hole $807 \mathrm{C}$ from a depth of 830 mbsf in Oligocene chalk to the oldest carbonates, MaastrichtianCampanian limestone, at a depth of 1351 mbsf (Kroenke, Berger, Janecek, et al., 1991). In the redeposited clast-rich part of the limestone in Hole $807 \mathrm{C}$, clasts are seen as a localizing factor for stylolites. Flaser structures are rare in the redeposited limestone interval below $1200 \mathrm{mbsf}$ in Hole $807 \mathrm{C}$, but flaser structures are common again near the bottom of the limestone section, from 1340 to 1351 mbsf overprinting centimeter-thick, limestone-clast-bearing, differentially compacted clay layers (Kroenke, Berger, Janecek, et al., 1991).

Centimeter-long, stylolite-associated fractures (tension gashes) oriented perpendicular to the stylolites are seen in the limestone part of the sedimentary column between 1230 and 1320 mbsf in Hole 807 C. According to Nelson (1985), tension gashes form as extension fractures in a triaxial stress field. This would imply tectonic influence, but possible sources for such an influence are not discussed in this paper.

Occurrences of stylolites and flaser structures at Site 807 are summarized in Table 1. A typical stylolite (with an amplitude exceeding the grain diameter) is shown in Plate 1, Figure 1. Typical microstylolites (part of flaser structure) are shown in Plate 1, Figure 2. The anastomosing pattern of microstylolites fits around the grains. Stylolites and flaser structures commonly intersect primary sedimentary structures (Plate 1, Figs. 3 and 4). Primary sedimentary structures (e.g., burrows or lithoclasts of a mineralogical composition in contrast 
Table 1. Summary of occurrences of stylolites and flaser structures at Site 807.

\begin{aligned} & \hline $\begin{array}{r}\text { Depth } \\ \text { (mbsf) }\end{array} \multicolumn{1}{c}{$ Event } \\ & \hline 490 Uppermost flaser structures \\ & 830 Uppermost stylolites \\ & 1200 Lowermost flaser structures in pure carbonate \\ & 1230 Uppermost tension gashes \\ & 1320 Lowermost tension gashes \\ & 1340 Uppermost sedintary clay layer overprinted by flaser structure \\ & 1351 Bottom of continuous carbonate section. \\ & \hline\end{aligned}

to that of the host sediment) can be seen as typical sites for localization of stylolites (Plate 2 and Plate 3, Figs. 1 and 2). Stylolites with associated tension gashes are presented on Plate 3, Figure 3 . The stylolites shown on Plate 2 are from the chalk section, and those on Plate 3 are from the limestone.

\section{PROCEDURES}

During the standard core description of Hole $807 \mathrm{C}$, the number, amplitude, and drape thickness of the stylolites and related structures were also recorded. The results are plotted in Figure 1. Stylolites and flaser structures were sampled in Hole $807 \mathrm{C} ; 1-\mathrm{cm}^{3}$ samples were collected for the measurement of carbon and oxygen isotope ratios. The samples were grouped in threes or fives as shown on Figure 2 , so that a possible signal related to the distance from the stylolite could be obtained. The isotope ratios were measured on bulk samples using the standard methods described by McCrea (1950). The samples were ground, and $20-30 \mathrm{mg}$ of powder was dissolved in $100 \%$ phosphoric acid in vacuum at $25^{\circ} \mathrm{C}$, for a dissolution time of $12-24 \mathrm{hr}$. The ${ }^{13} \mathrm{C} /{ }^{12} \mathrm{C}$ and ${ }^{18} \mathrm{O} /{ }^{16} \mathrm{O}$ ratios of the evolved carbon dioxide gas were measured in the Finnigan MAT 250 triple collector mass spectrometer of the Geological Institute, University of Copenhagen. An error of $\pm 0.03 \%$ is estimated for $\delta^{13} \mathrm{C}$, and an error of $\pm 0.07 \%$ is estimated for $\delta^{18} \mathrm{O}$. The results are plotted in Figure 3.

\section{RESULTS}

The abundance of the stylolites (Fig. 1A) shows an erratic pattern in the poorly recovered chert-rich chalk above 1100 mbsf. In the limestone, below roughly $1100 \mathrm{mbsf}$, an overall increase with depth in stylolite abundance is suggested; however, large local variations are evident. In Figure $1 \mathrm{C}$ the maximum amplitudes of the stylolites in Hole 807C are recorded as a function of depth. The amplitudes tend to be high in the interval at about $1200 \mathrm{mbsf}$, where stylolite frequencies are low, but no obvious overall pattern can be deduced. The maximum thicknesses of the clay drapes are plotted on Figure 1D. No obvious relationships exist between either drape thicknesses and amplitudes or drape thicknesses and stylolite frequencies.

The oxygen and carbon isotope ratio analyses (Fig. 3) showed no contrast between stylolite-bearing samples and neighboring matrix samples. Material from flaser structures and from near stylolites falls along the same general isotope ratio trends. The overall isotope pattern for Hole $807 \mathrm{C}$ is discussed by Corfield (this volume).

\section{DISCUSSION}

The localization of stylolites along burrows and lithoclasts and the irregular occurrence and size of stylolites indicate that stylolites and flaser structures can be interpreted as the results of diagenetic processes along preexisting sedimentary or diagenetic structures. This is in line with Heald's (1955) hypothesis that clay should be a localizing factor for stylolite formation.

Bathurst (1987) found that dissolution seams (flaser structures) are typical of argillaceous carbonate sediments, with more than $8 \%-10 \%$ clay, whereas stylolites are typical of purer carbonate sediments. In line with this observation, flaser structures overprint the clay layers in the lowest part of the Hole $807 \mathrm{C}$ limestone sequence. Nevertheless, flaser structures are also common in the purer chalk and limestone intervals.

The present observations indicate that the nature of the preexisting structure in the chalk or limestone determines whether flaser structures or stylolites form. Finely disseminated clay (and other non-calcite minerals?) would tend to give rise to microstylolites and thereby a flaser structure. Finely disseminated clay and pyrite are found in color bands (Lind, Janecek, et al., this volume). More concentrated clay (e.g., a Zoophycos burrow or clay clasts) would tend to result in a stylolite. By the formation of microstylolites, clays are concentrated, and thus flaser structures could act as precursors for stylolites. The shallower uppermost occurrence of flaser structures relative to stylolites in the cores indicates that flaser structures may develop into true stylolites with prograding diagenesis of not too argillaceous chalk or limestone.

No positive indication of possible local dissolution or precipitation was obtained from the isotope data. Major removal of carbonate along stylolites as a consequence of pressure dissolution and reprecipitation of carbonate in the neighboring matrix could have resulted in an isotopic contrast between stylolite-bearing samples and neighboring matrix samples.

\section{SUMMARY}

In the cores from Hole $807 \mathrm{C}$, an overall increase in stylolite abundance with depth is indicated, but the pattern has many local variations. Stylolite amplitudes and thicknesses have an even more irregular depth-wise distribution.

From the routine core descriptions, stylolites and flaser structures were noted crossing sedimentary structures. However, horizontal or nearly horizontal structures, such as Zoophycos burrows and color bands, can be partly replaced by flaser structures and stylolites.

These observations indicate that a mineralogical anomaly is an initializing factor in stylolite formation. Diffuse anomalies, such as color bands, may be precursors for flaser structures. More concentrated anomalies, such as Zoophycos burrows, shale clasts, or even flaser structures, may be precursors for stylolites.

Oxygen and carbon isotope analyses of material from stylolites and flaser structures and from their host carbonate sediments did not indicate any local enrichment or depletion in heavy isotopes along the structures. Thus, transport of dissolved material away from the structures could not be documented.

\section{ACKNOWLEDGMENTS}

Help and advice are acknowledged from B. Buchardt, V. Knudsen, I. Nygaard, A. Steffensen, A. Syberg, I. Søndergaard, and B. Warming. K. Warner corrected the English text.

\section{REFERENCES}

Andrews, J.E., Packham, G., et al., 1975. Init. Repts. DSDP, 30: Washington (U.S. Govt. Printing Office).

Bathurst, R.G.C., 1987. Diagenetically enhanced bedding in argillaceous platform limestones: stratified cementation and selective compaction. Sedimentology, 34:749-778.

Heald, M.T., 1955. Stylolites in sandstones. J. Geol., 63:101-114.

Kroenke, L.W., Berger, W.H., Janecek, T.R., et al., 1991. Proc. ODP, Init. Repts., 130: College Station, TX (Ocean Drilling Program).

McCrea, J.M., 1950. The isotopic chemistry of carbonates and a paleotemperature scale. J. Chem. Phys., 18:849-857.

Nelson, R.A., 1985. Geologic Analysis of Naturally Fractured Reservoirs: Houston (Gulf Publishing).

Ryan, W.B.F., Hsü, K.J., et al., 1973. Init. Repts. DSDP, 13: Washington (U.S. Govt. Printing Office).

Date of initial receipt: 3 September 1991

Date of acceptance: 11 May 1992

Ms 130B-006 

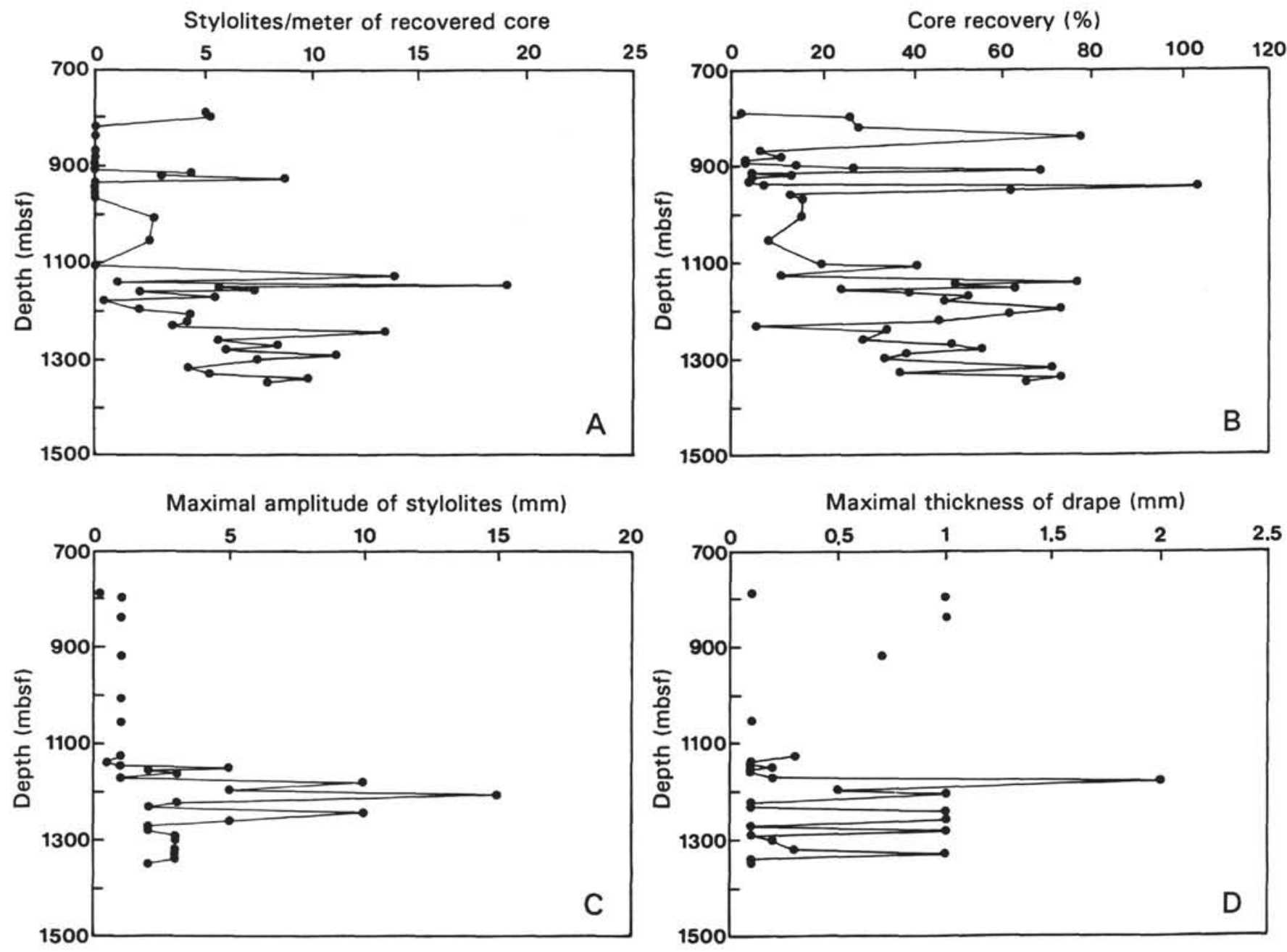

Figure 1. Number and size of stylolites, Hole 807C. A. Abundance of stylolites as a function of depth. B. Core recovery. C. Maximum amplitudes of the individual stylolites. D. Maximum thickness of clay drapes on stylolites.

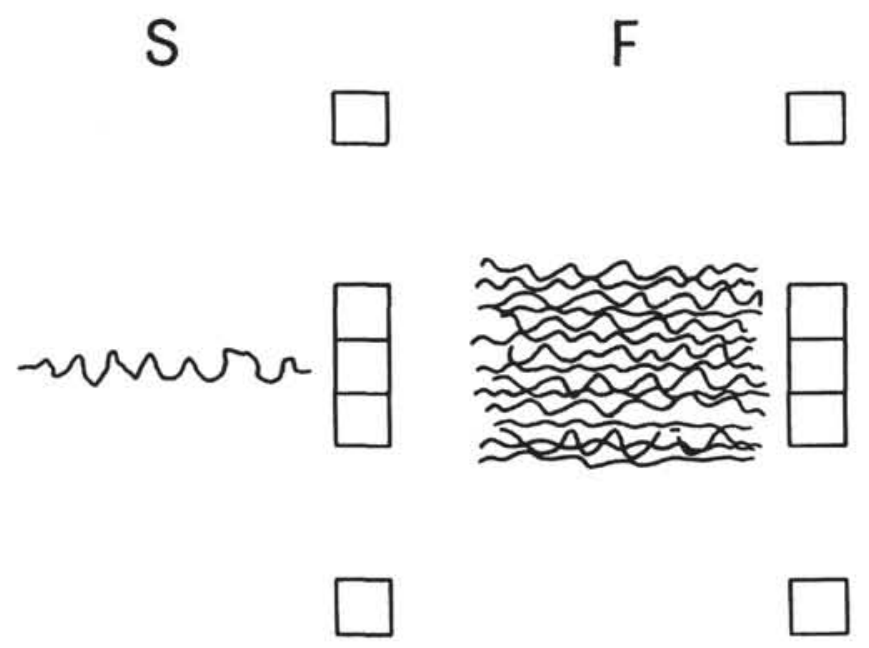

Figure 2. Position of $1-\mathrm{cm}^{3}$ samples collected for isotope analysis relative to stylolites (S) and flaser structures (F). 


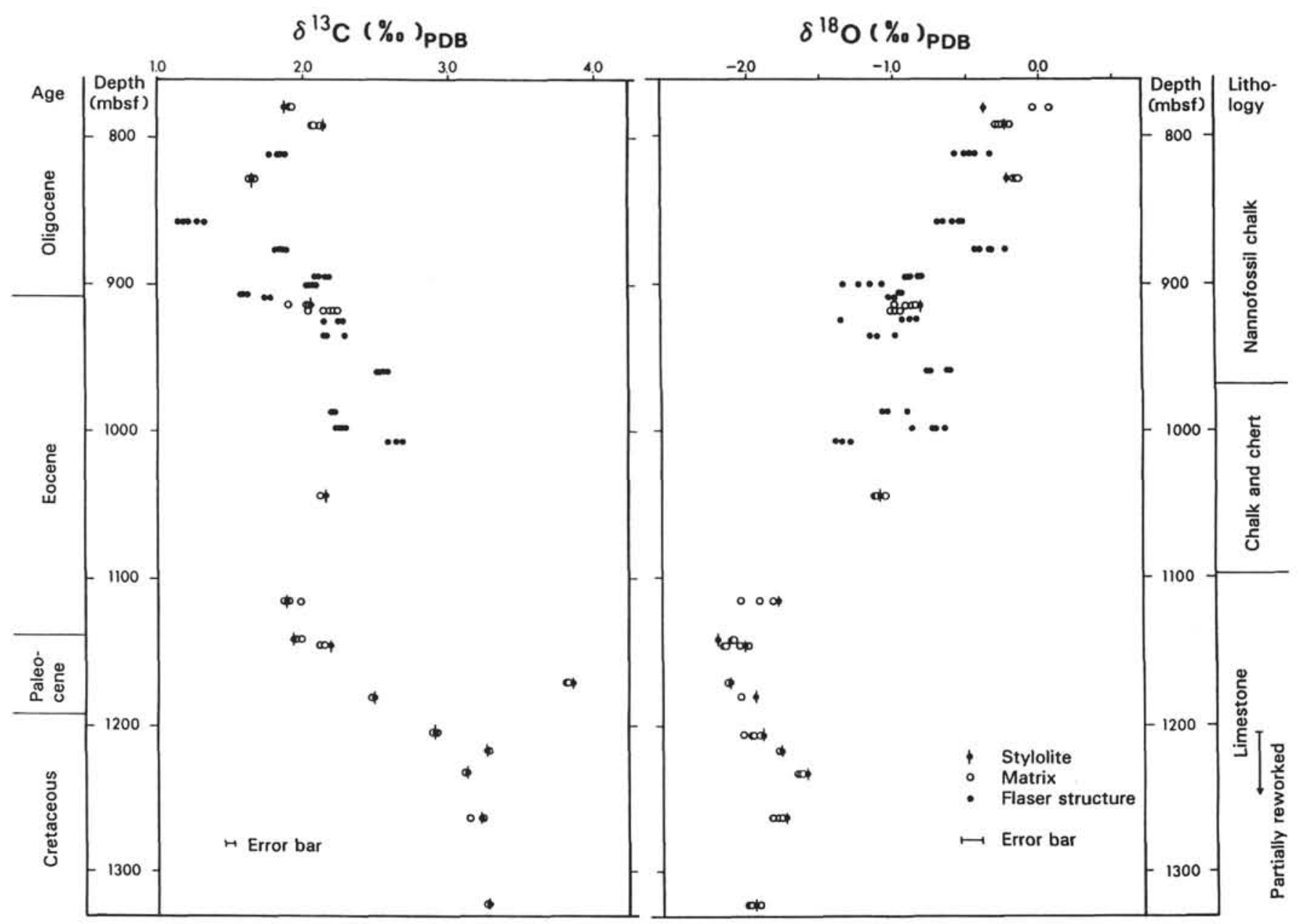

Figure 3. Oxygen and carbon isotope data for stylolite- and flaser-structure-related samples of Hole 807C. 


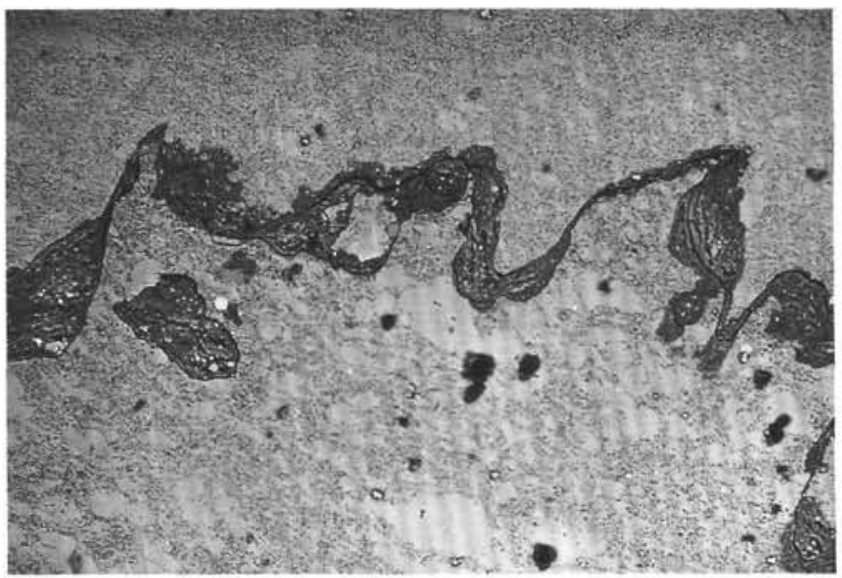

1

$1 \mathrm{~mm}$

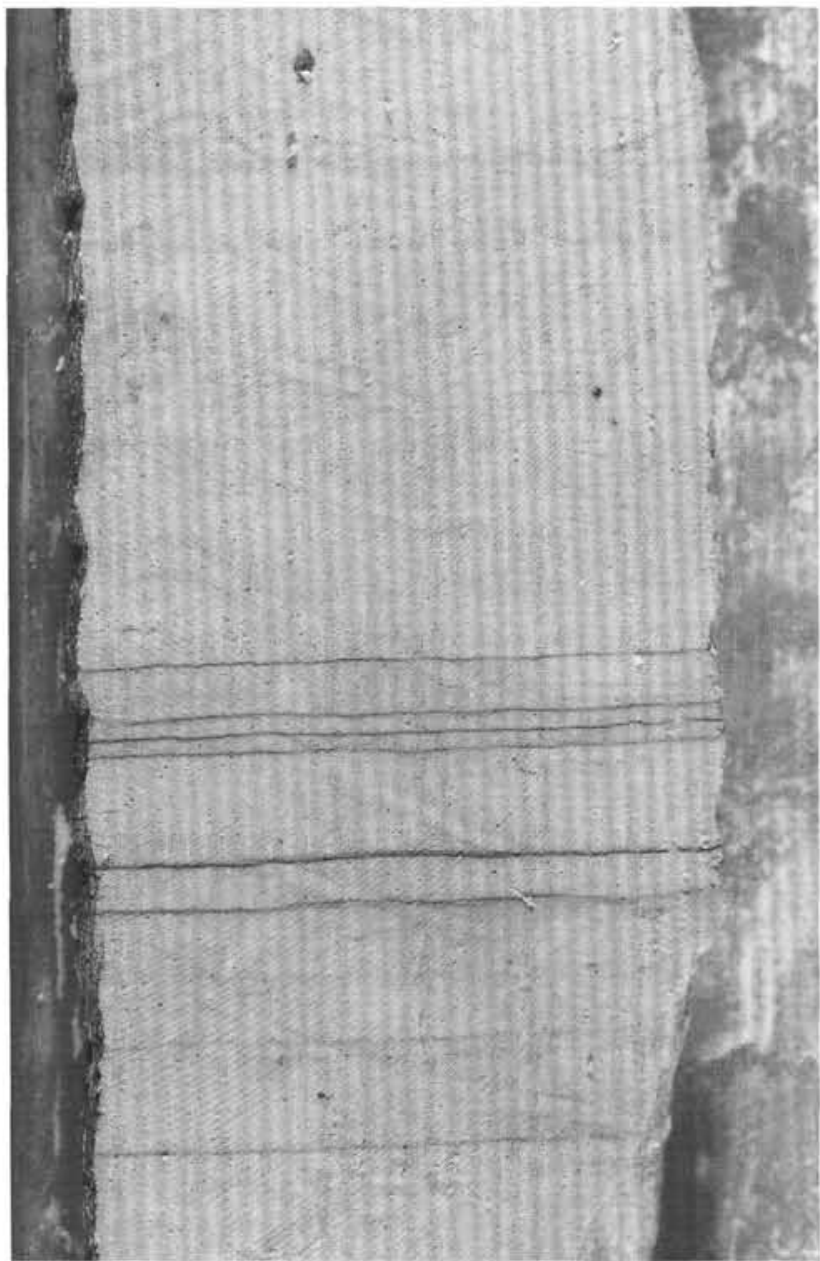

3
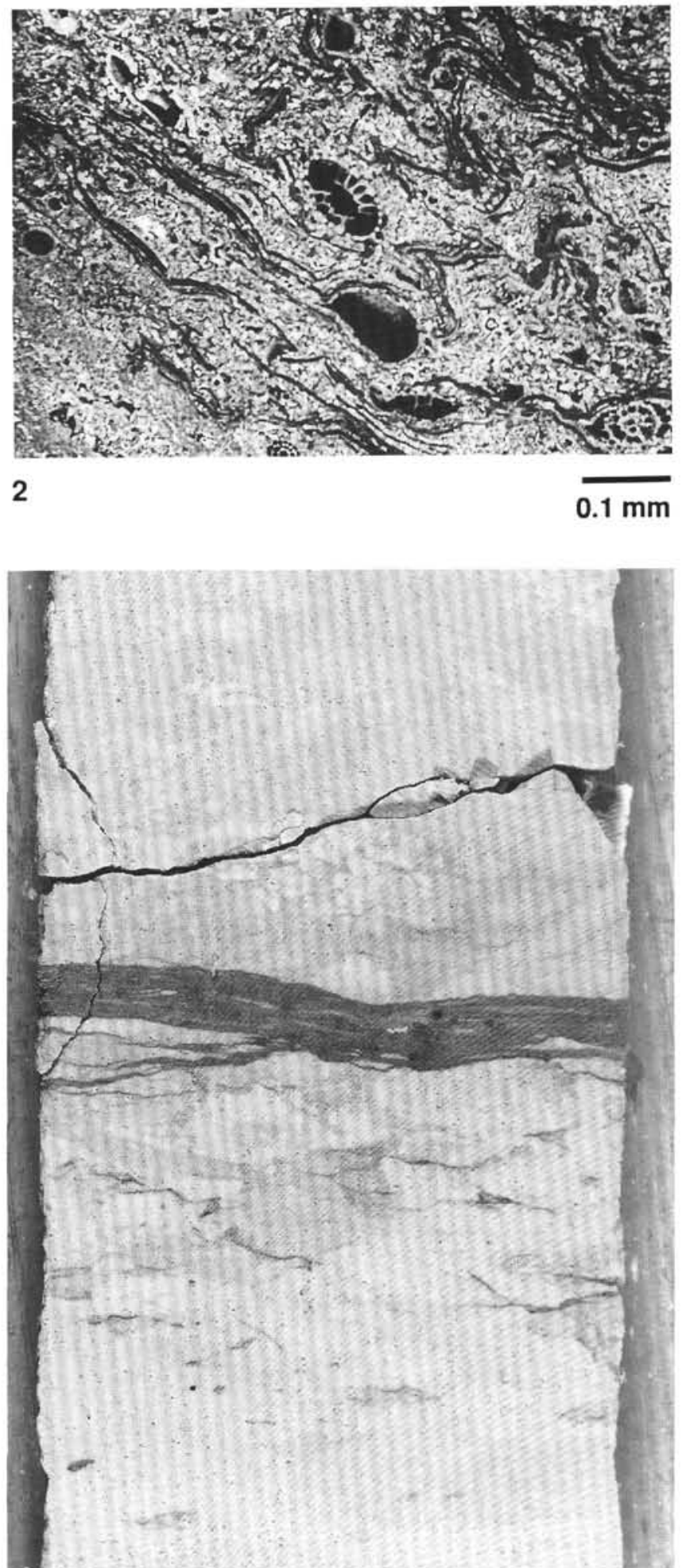

4

Plate 1. 1. Backscatter electron micrograph of a stylolite from Section 130-807C-56R-1, 13-15 cm. 2. Backscatter electron micrograph of a flaser structure from Section 130-807C-53R-2, 22-24 cm. 3. Fine-scale stylolites crossing the trace fossil Zoophycos in Section 130-806B-70X-3, 53-63 cm. 4. Flaser structure truncating a clast-bearing interval in Section 130-807C-6R-4, 106-116 cm. 
1

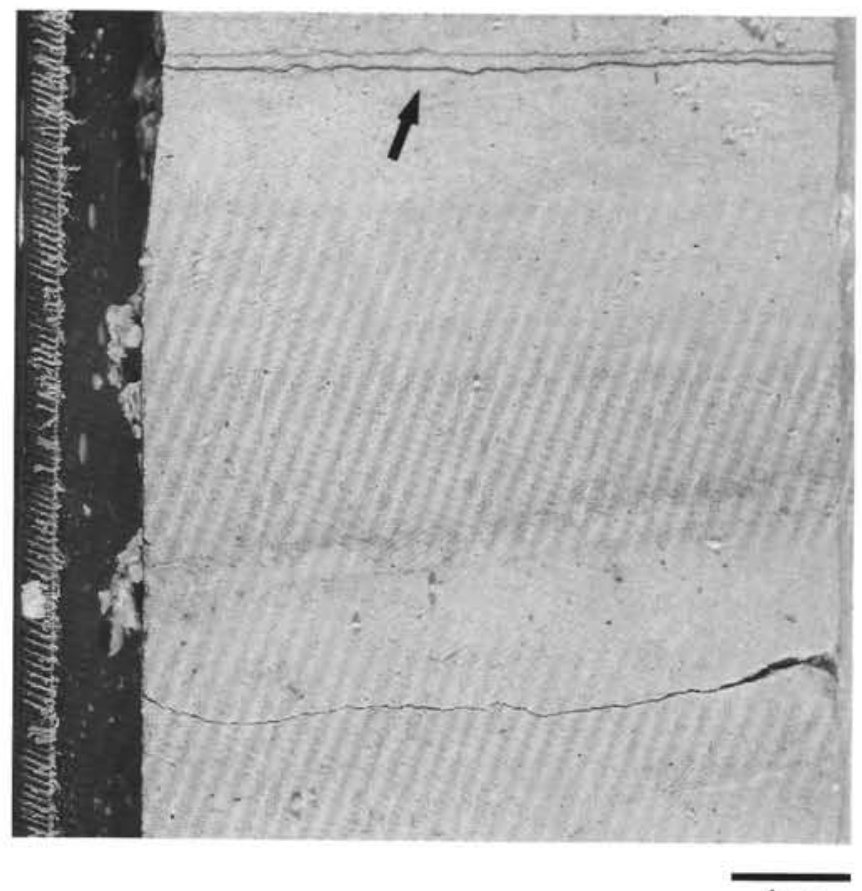

2

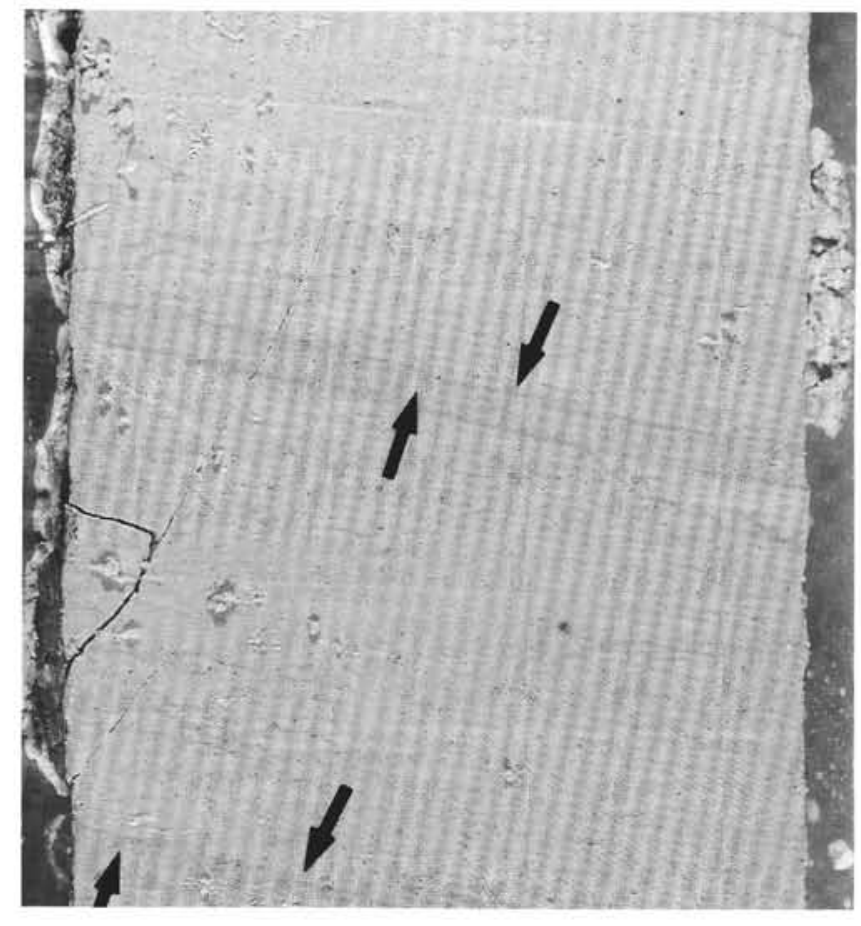

$1 \mathrm{~cm}$

3

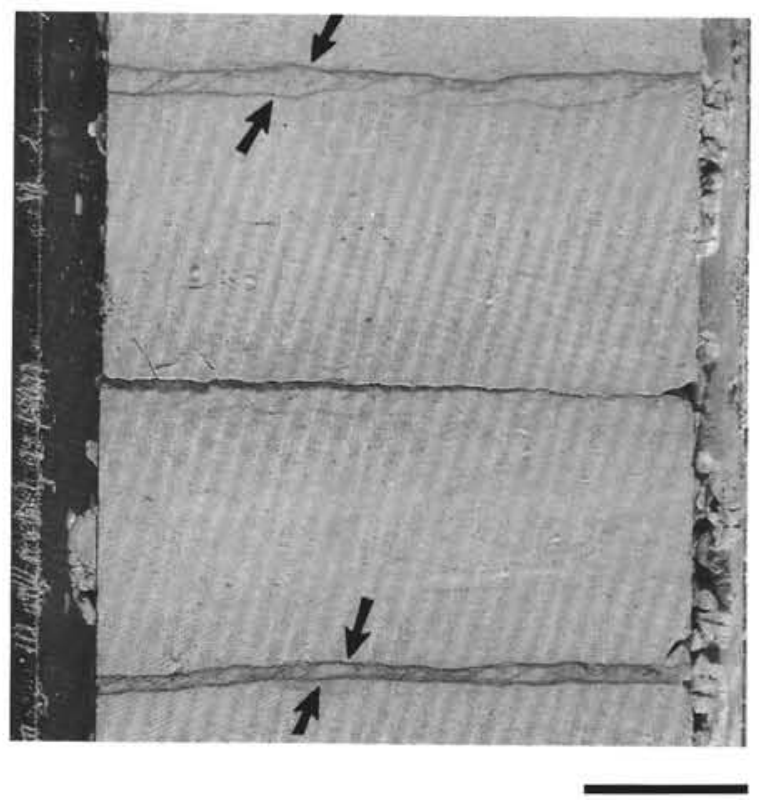

$1 \mathrm{~cm}$
4

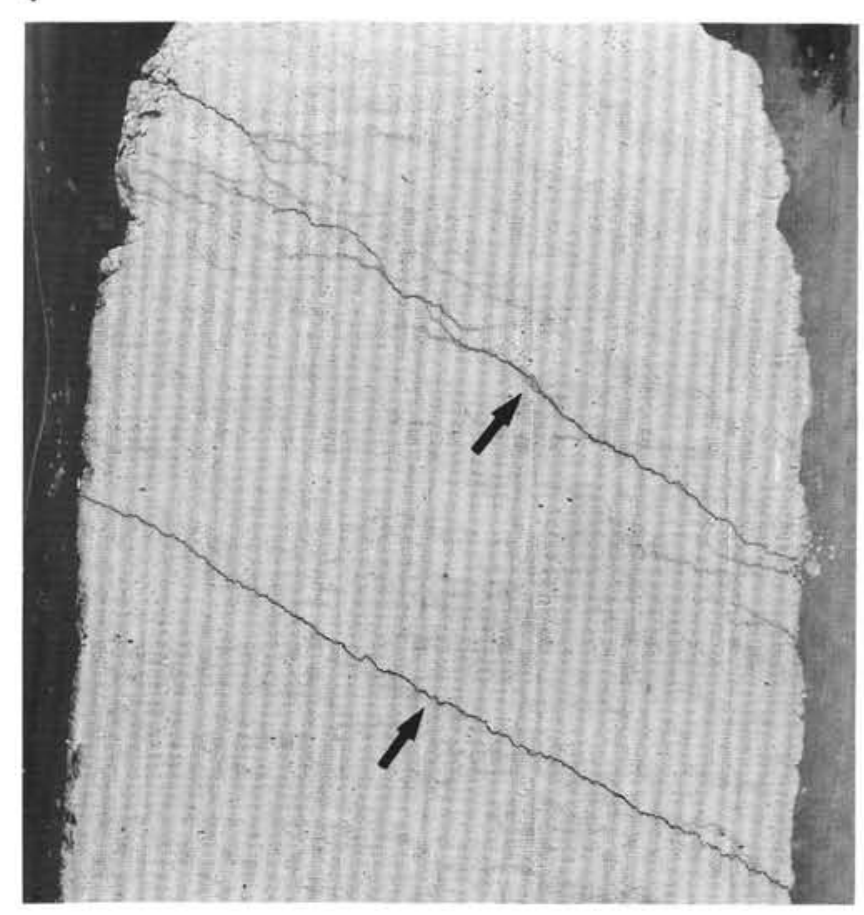

$1 \mathrm{~cm}$

Plate 2. 1. Interval with very fine stylolites (arrow) and a Zoophycos burrow. Section 130-806B-76X-3, 29-36 cm. 2. Part of a Zoophycos burrow system where very fine stylolites (arrows) are outlining the traces. Section 130-807A-71X-3, 116-123 cm. 3. Part of a Zoophycos burrow system. Stylolites (arrows) outline and partly erase the traces. Section 130-806B-76X-3, 83-90 cm. 4. Inclined stylolites (arrows). Their spacing and inclination indicate that they possibly outline a now-obliterated Zoophycos burrow. Section 130-807C-35R-1, 3-10 cm. 
1

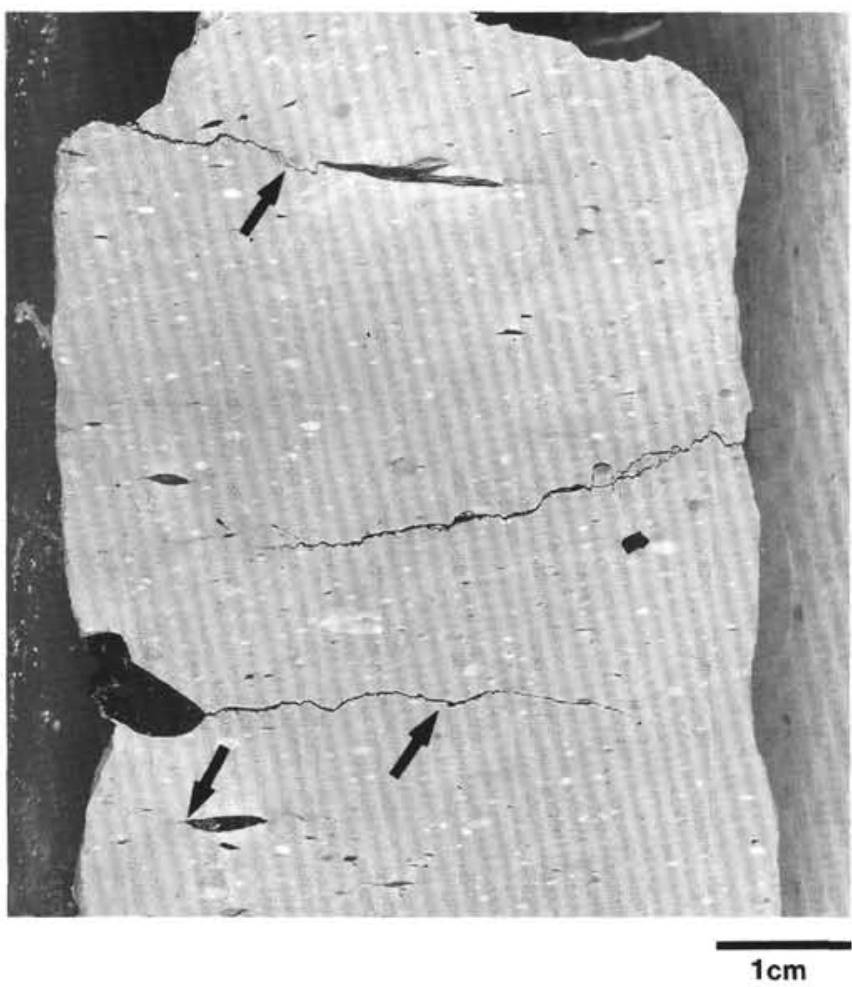

3

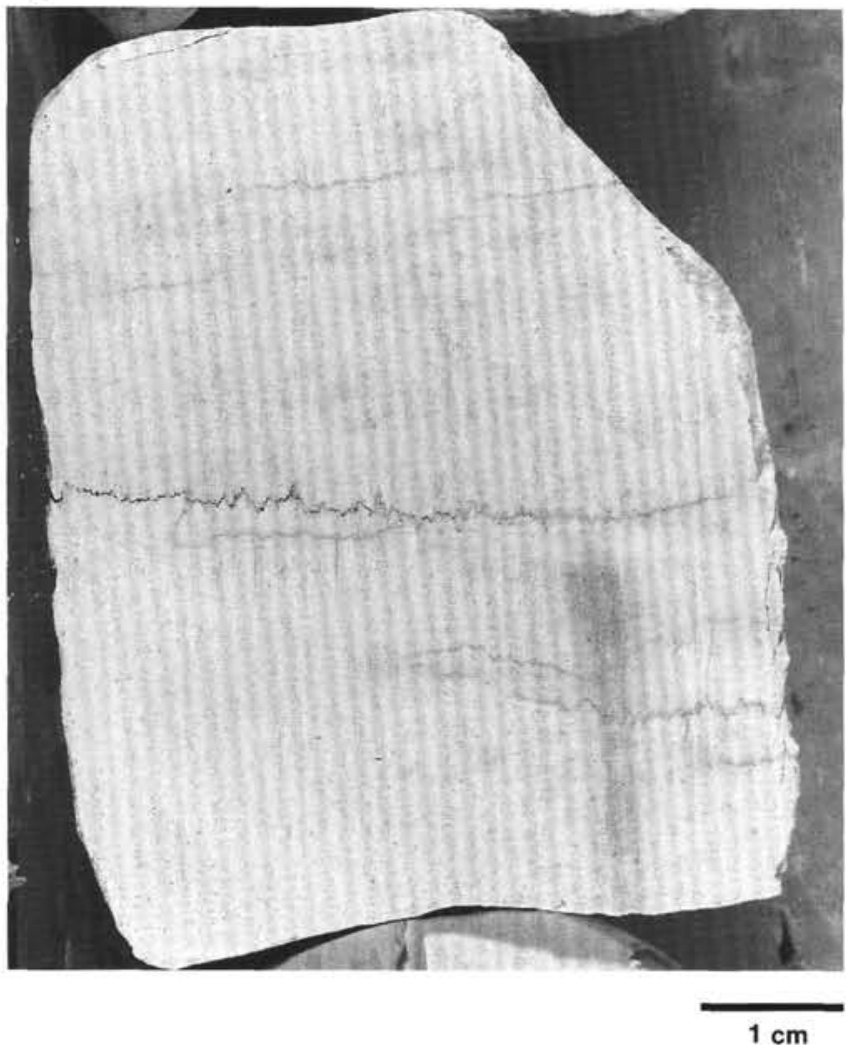

2

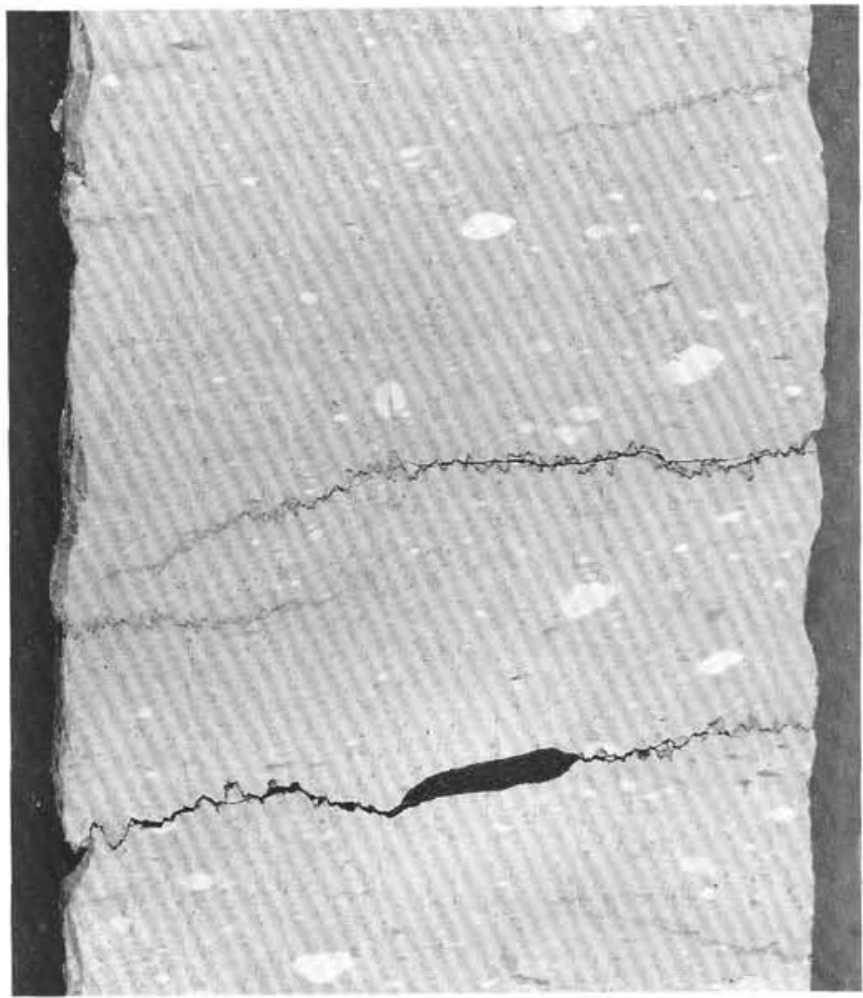

$1 \mathrm{~cm}$

\section{4}

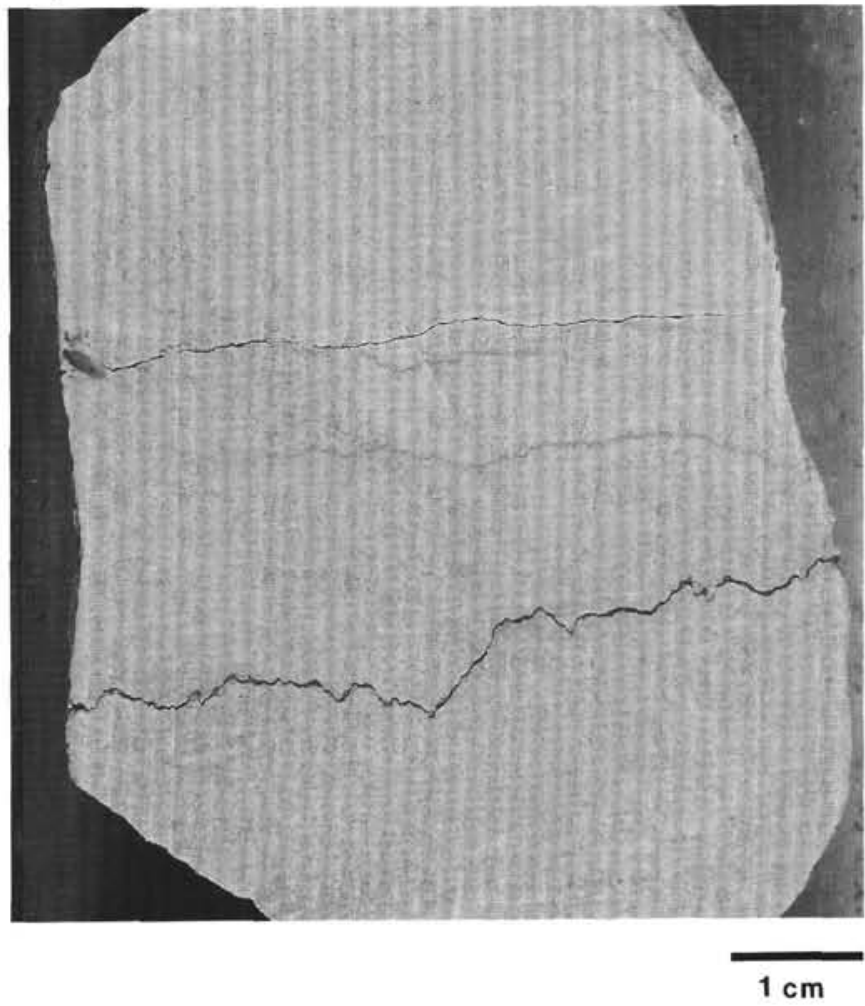

Plate 3. 1. Shale clasts in limestone localizing small noncontinuous stylolites (arrows). Section 130-807C-69R-1, 17-24 cm. 2. Shale clast within a stylolite. Section 130-807C-59R-2, 83-90 cm. 3. Tension gashes terminating at a stylolite. Section 130-807C-61R-1, $42-49 \mathrm{~cm}$. 4. Stylolite (the lowest) with relatively large amplitude. Section 130-807C-48R-1, 38-45 cm. 